\title{
Genetic Variability Study in Segregating Generations of Okra (Abelmoschus esculentus L.)
}

\author{
Tukaram A. Chavan ${ }^{1}$, P. B. Wadikar ${ }^{1}$, B. R. Chavan ${ }^{2}$ and G. H Naik ${ }^{1}$ \\ ${ }^{1}$ College of Agriculture, Latur, India \\ ${ }^{2}$ College of Agriculture, Parbhani, V. N. Marathwada Agriculture University, \\ Parbhani-431402 (M.S.), India \\ *Corresponding author
}

\section{A B S T R A C T}

\section{Keywords \\ okra, F2, F3, $\mathrm{BC} 1 \mathrm{~F} 2$ and $\mathrm{BC} 2 \mathrm{~F} 2$ generation.}

\section{Article Info}

Accepted:

22 August 2019

Available Online:

10 September 2019

\begin{abstract}
Segregating generations $\mathrm{F}_{2}, \mathrm{~F}_{3}, \mathrm{BC}_{1} \mathrm{~F}_{2}$ and $\mathrm{BC}_{2} \mathrm{~F}_{2}$ were evaluated in randomized block design with three replication at Experimental Farm, Department of Agricultural Botany, College of Agriculture, Latur, Vasantrao Naik Marathwada Krishi Vidyapeeth, Parbhani during kharif 2017. The observations were recorded for traits days of first flowering (days), plant height $(\mathrm{cm})$, intermodal length $(\mathrm{cm})$, number of branches per plant, number of nodes per plant, fruit length $(\mathrm{cm})$, fruit weight $(\mathrm{g})$, fruit diameter $(\mathrm{mm})$, number of fruits per plant, fruit yield per plant (g) for examine the genetic variability in segregating generations in the cross Arka Bahar x IC31032A. The data pertaining to the analysis of variance revealed that treatment variances were found highly significant for all the characters indicating presence of considerable amount of variability in the experimental material used in the present study. Mean performance revealed the superiority of Arka Bahar for internodal length, number of nodes per plant and length of fruit, IC31032A for fruit diameter, $\mathrm{F}_{1}$ for plant height and number of branches per plant, $\mathrm{BC}_{2} \mathrm{~F}_{1}$ for number of fruit per plant and fruit yield per plant, $\mathrm{F}_{2}$ for early flowering, and fruit weight. The estimated of high genotypic and phenotypic coefficient of variation were observed for number of nodes per plant and fruit weight in $F_{2}$ generation, internodal length in $F_{3}$ generation, plant height, number of branches per plant, fruit diameter, number of fruit per plant and fruit yield per plant in $\mathrm{BC}_{1} \mathrm{~F}_{2}$ generation, length of fruit in $\mathrm{BC}_{2} \mathrm{~F}_{2}$ generation. The estimated of heritability was appreciably moderate for fruit weight in $\mathrm{BC}_{1} \mathrm{~F}_{2}$. Higher heritability indicated less influence of environments. The genetic advance as per cent of mean was appreciably high for fruit yield per plant in $\mathrm{BC}_{1} \mathrm{~F}_{2}$ and moderate for fruit weight and number of fruit per plant in $\mathrm{F}_{2}$ and $\mathrm{BC}_{1} \mathrm{~F}_{2}$ generation respectively. High GAM indicated influence of additive genetic action.
\end{abstract}

\section{Introduction}

Okra (Abelmoschus esculentus L.) is an annual herbaceous important vegetable crop that is grown for its young immature green fruit and fresh leaves in the tropical and subtropical parts of the world. Okra is generally self pollinated and belongs to family Malvaceae with $2 \mathrm{n}=130$ chromosomes and amphidiploids in nature. Out of 34 species of Abelmoschus 
only the species Abelmoschus esculentus is known to be cultivated in extensively as commercial vegetable. Okra is usually consumed for its green tender fruits as a vegetable in a variety of ways. The tender fruits are used as vegetable, eaten boiled or in culinary preparations as sliced and fried pieces. Its average nutritive value is higher than tomato, egg plant and most of the cucurbits Evaluation of potentialities of the existing cultivars is essential because it depicts the genetic diversity of the base materials on which depends the promise for further improvement. The success of a breeding programme for the improvement of quantitative attributes depends to a great extent on the magnitude of genetic variability existing in the germplasm. Burton (1952) suggested that genetic variability along with heritability should be considered for assessing the maximum and accurate effect of selection. Studies on the variability using genetic parameters like genotypic coefficient of variation (GCV), heritability and genetic advance is essential for initiating an efficient breeding programme. High yield can be achieved by selection of those characters that have high heritability values coupled with high genetic advance. Selection is an indispensable component of variety development process.

\section{Materials and Methods}

The experimental material was developed by involving two genetic diverse genotype viz. Arka Bahar and IC31032A, maintained through continuous selfing. The cross, Arka Bahar x IC31032A was effected in kharif, 2015-16 by hand emasculation and pollination. The $\mathrm{F}_{1}$ 's and parents were grown in summer, 2016 to advance the $\mathrm{F}_{2}$ 's and to prepare $\mathrm{BC}_{1}$ and $\mathrm{BC}_{2}$ crosses. The $\mathrm{F}_{2}$ 's, $\mathrm{BC}_{1}$ and $\mathrm{BC}_{2}$ were grown and selfed during Kharif, 2016 to advance $\mathrm{F}_{3}, \mathrm{BC}_{1} \mathrm{~F}_{2}$ and $\mathrm{BC}_{2} \mathrm{~F}_{2}$ generation. Thus seed of nine generation, $\mathrm{P}_{1}$,
$\mathrm{P}_{2}, \mathrm{~F}_{1}, \mathrm{~F}_{2}, \mathrm{~F}_{3}, \mathrm{BC}_{1}, \mathrm{BC}_{2}, \mathrm{BC}_{1} \mathrm{~F}_{2}, \mathrm{BC}_{2} \mathrm{~F}_{2}$ and Parbhani kranti was considered as a local check to evaluate segregating generations during kharif, 2017. The experiment was conducted at experimental farm, department of agricultural botany, college of agriculture, Latur. The observations was recorded for characters ten characters on randomly selected five plants in $\mathrm{P}_{1}, \mathrm{P}_{2}, \mathrm{~F}_{1}, \mathrm{BC}_{1}, \mathrm{BC}_{2}$ and Parbhani kranti and each plant in $\mathrm{F}_{2}, \mathrm{~F}_{3}, \mathrm{BC}_{1} \mathrm{~F}_{2}$ and $\mathrm{BC}_{2} \mathrm{~F}_{2}$ generation in each replication. Analysis of variance was carried out as per standard method of Panse and Sukhatme, 1954. The variance parameters of variability analysis were carried out as per Burton (1953).

\section{Results and Discussion}

\section{Analysis of variance}

The analysis of variance for genetic variability, heterosis and inbreeding depression in segregating generations was carried out for all studied ten characters revealed that mean sum of square for treatments in Arka Bahar x IC31032A cross showed highly significant differences for all the characters. This indicated existence of sufficient variation for effective selection for all the characters in the material under studied depicted in table 3.1 .

\section{Genetic variability, heritability and genetic advance}

Day to first flowering was recorded moderate phenotypic coefficient of variation in $\mathrm{BC}_{1} \mathrm{~F}_{2}$ (13.20\%) generation. Low PCV recorded for $\mathrm{F}_{2}, \mathrm{~F}_{3}$, and $\mathrm{BC}_{2} \mathrm{~F}_{2}$ generations. Low genotypic coefficient of variation was observed for all the generations respectively. For days to first flowering, the moderate PCV and GCV values were exhibited by the $\mathrm{BC}_{1} \mathrm{~F}_{2}$ population. Moderate heritability coupled with low genetic advance as per cent mean for $\mathrm{BC}_{1} \mathrm{~F}_{2}$ generation. The result obtained in the present 
study was in accordance with report of Badiger et al., (2017), Akotkar et al., (2010), Meena et al., (2013), Guddadamath et al., (2011), Sravanth (2017).

Highest phenotypic coefficient of variation with moderate genotypic coefficient of variation was recorded for plant height $(\mathrm{cm})$ in all segregating generations. The heritability for this trait was low for all generations. Among the different generations $\mathrm{F}_{2}$ progeny was moderate heritability coupled with low genetic advance as per cent mean and high PCV and moderate GCV. The result obtained confirm the earlier report of Sharma et al.,(2014), Guddadamath et al., (2011), Mehta et al., (2006), Sravanth (2017), Kandasamy (2015).

The low heritability for internodal length $(\mathrm{cm})$ was identified in $\mathrm{F}_{3}$ followed by $\mathrm{BC}_{1} \mathrm{~F}_{2}, \mathrm{BC}_{2} \mathrm{~F}_{2}$ and $F_{2}$ generations. $F_{3}$ progenies had moderate heritability coupled with moderate genetic advance as per cent mean. $\mathrm{F}_{3}$ was recorded high PCV and moderate GCV followed by $\mathrm{F}_{2}$, $\mathrm{BC}_{2} \mathrm{~F}_{2}$, and $\mathrm{BC}_{1} \mathrm{~F}_{2}$ population. Similar result reported by Badiger et al., (2017), Simon et al., (2013), Meena et al., (2013), Singh et al., (2017), Goswami (2014), Mallesh (2015).

$\mathrm{BC}_{1} \mathrm{~F}_{2}$ progenies had low heritability coupled with high genetic advance as per cent mean. $\mathrm{BC}_{1} \mathrm{~F}_{2}$ was recorded very high $\mathrm{PCV}$ and GCV followed by $\mathrm{F}_{2}, \mathrm{~F}_{3}$, and $\mathrm{BC}_{2} \mathrm{~F}_{2}$ population for the character number of branches per plant. This was in accordance with report of Yonas et al., (2014), Meena et al., (2013), Guddadamath et al., (2011), Shivaramegowda et al.,(2016), Singh et al., (2017)

The value of PCV and GCV recoded high and moderate respectively in $F_{2}$ for the trait number of nodes per plant. $\mathrm{F}_{2}$ progenies had low heritability with moderate genetic advance expressed as per cent mean. The result obtained confirm the earlier report of
Yonas et al., (2014), Meena et al., (2013), Guddadamath et al., (2011), Singh et al., (2017). Genotypic coefficient of variability was observed for trait length of fruit $(\mathrm{cm})$ $12.66,16.33,20.00$ and 18.84 percent in $F_{2}$, $\mathrm{F}_{3}, \mathrm{BC}_{1} \mathrm{~F}_{2}$ and $\mathrm{BC}_{2} \mathrm{~F}_{2}$ generations respectively. Phenotypic coefficient of variability was observed 28.29, 37.48, 34.41 and 38.02 percent in $\mathrm{F}_{2}, \mathrm{~F}_{3}, \mathrm{BC}_{1} \mathrm{~F}_{2}$ and $\mathrm{BC}_{2} \mathrm{~F}_{2}$ generations respectively. Across different population $\mathrm{BC}_{2} \mathrm{~F}_{2}$ was recorded high $\mathrm{PCV}$ and moderate GCV. $\quad \mathrm{BC}_{2} \mathrm{~F}_{2}$ progenies had moderate heritability coupled with high genetic advance as per cent mean for length of fruit $(\mathrm{cm})$. The result obtained confirm the earlier report of Singh et al., (2017), Meena et al., (2013), Shivaramegowda et al.,(2016).

The fruit diameter $(\mathrm{mm})$ was recorded high and moderate PCV and GCV value respectively by the $\mathrm{BC}_{1} \mathrm{~F}_{2}$ generation. $\mathrm{BC}_{1} \mathrm{~F}_{2}$ progenies had low heritability with moderate genetic advance expressed as per cent of mean for fruit diameter.

The result obtained in the present study was accordance with report of Akotkar et al., (2010), Guddadamath et al., (2011), Yonas et al., (2014), Das et al., (2012), Mehta et al., (2006).

Value of PCV and GCV for number of fruit per plant identified high and moderate respectively in $\mathrm{BC}_{1} \mathrm{~F}_{2} . \mathrm{BC}_{1} \mathrm{~F}_{2}$ progenies had low heritability coupled with moderate genetic advance expressed as per cent mean.

The result obtained confirm the earlier report of Guddadamath et al., (2011), Yonas et al., (2014), Sharma et al.,(2014), Sala and Shanthi (2016).

Generation $F_{2}$ was recorded for fruit weight high PCV and moderate GCV. $\mathrm{F}_{2}$ progenies had low heritability coupled with moderate genetic advance expressed as per cent mean. 
Table.1 Analysis of variance for different characters in okra

\begin{tabular}{|l|l|c|c|c|c|c|}
\hline $\begin{array}{l}\text { Source } \\
\text { of variance }\end{array}$ & d.f. & $\begin{array}{c}\text { Days to } \\
\text { first } \\
\text { flowering }\end{array}$ & $\begin{array}{c}\text { Plant } \\
\text { height } \\
\text { (cm) }\end{array}$ & $\begin{array}{c}\text { Inter-nodal } \\
\text { length } \\
\text { (cm) }\end{array}$ & $\begin{array}{c}\text { No. of } \\
\text { branches per } \\
\text { plant }\end{array}$ & $\begin{array}{c}\text { No. of } \\
\text { nodes } \\
\text { per plant }\end{array}$ \\
\hline Replication & 2 & 0.08 & 355.45 & 2.27 & 0.05 & 2.83 \\
\hline Treatment & 9 & $8.32^{* *}$ & $1062.95^{* *}$ & $2.93^{* *}$ & $0.14^{* *}$ & $15.31^{* *}$ \\
\hline Error & 18 & 0.92 & 101.86 & 0.76 & 0.02 & 1.10 \\
\hline $\begin{array}{l}\text { Source of } \\
\text { variance }\end{array}$ & d.f. & $\begin{array}{l}\text { Length of } \\
\text { fruit (cm) }\end{array}$ & $\begin{array}{c}\text { Fruit } \\
\text { diameter } \\
\text { (mm) }\end{array}$ & $\begin{array}{c}\text { No. of fruit } \\
\text { per plant }\end{array}$ & $\begin{array}{c}\text { Fruit Weight } \\
\text { (g) }\end{array}$ & $\begin{array}{c}\text { Fruit yield } \\
\text { per plant(g) }\end{array}$ \\
\hline Replication & 2 & 2.94 & 2.92 & 2.35 & 1.69 & 1304.71 \\
\hline Treatment & 9 & $34.78^{* *}$ & $31.42^{* *}$ & $12.95^{* *}$ & $8.73^{* *}$ & $6645.13^{* *}$ \\
\hline Error & 18 & 1.97 & 1.53 & 2.45 & 1.50 & 725.66 \\
\hline
\end{tabular}

$* *$ and $*$ indicates significant at $1 \%$ and $5 \%$, respectively

Table.2 Estimation of genetic variability parameters for ten quantitative traits in $\mathrm{F}_{2}, \mathrm{~F}_{3}, \mathrm{BC}_{1} \mathrm{~F}_{2}$ and $\mathrm{BC}_{2} \mathrm{~F}_{2}$ generation of okra

\begin{tabular}{|c|c|c|c|c|c|c|c|}
\hline Generation & Mean & Range & PCV & GCV & $\begin{array}{l}\mathbf{h}^{2} \\
(\%)\end{array}$ & GA & $\operatorname{GAM}(\%)$ \\
\hline \multicolumn{8}{|c|}{ 1. Days to First Flowering } \\
\hline $\mathbf{F}_{2}$ & 38.13 & 35.00 to 42.00 & 8.016 & 3.36 & 17.60 & 1.10 & 2.90 \\
\hline $\mathbf{F}_{3}$ & 38.36 & 35.30 to 42.00 & 8.11 & 3.58 & 19.50 & 1.25 & 3.20 \\
\hline $\mathbf{B C}_{1} \mathbf{F}_{2}$ & 43.45 & 38.00 to 52.00 & 13.0 & 7.71 & 35.20 & 4.10 & 9.40 \\
\hline $\mathrm{BC}_{2} \mathrm{~F}_{2}$ & 39.69 & 37.00 to 48.00 & 7.53 & 4.23 & 31.50 & 1.94 & 4.89 \\
\hline \multicolumn{8}{|c|}{ 2. Plant Height (cm) } \\
\hline $\mathbf{F}_{2}$ & 150.11 & 85.00 to 206.66 & 26.88 & 11.33 & 17.80 & 14.77 & 9.84 \\
\hline $\mathbf{F}_{\mathbf{3}}$ & 137.43 & 95.00 to 190.00 & 23.83 & 10.09 & 17.90 & 12.10 & 8.80 \\
\hline $\mathrm{BC}_{1} \mathrm{~F}_{2}$ & 128.85 & 91.66 to 181.66 & 26.51 & 15.65 & 34.90 & 24.54 & 19.04 \\
\hline $\mathrm{BC}_{2} \mathbf{F}_{2}$ & 154.68 & 101.60 to 203.30 & 25.29 & 13.34 & 27.90 & 22.45 & 14.51 \\
\hline \multicolumn{8}{|c|}{ 3. Internodal Length (cm) } \\
\hline $\mathbf{F}_{2}$ & 8.57 & 5.30 to 11.60 & 23.88 & 10.467 & 19.20 & 0.81 & 9.44 \\
\hline $\mathbf{F}_{3}$ & 7.66 & 5.44 to 11.66 & 24.23 & 14.15 & 34.10 & 1.30 & 17.03 \\
\hline $\mathrm{BC}_{1} \mathbf{F}_{2}$ & 9.59 & 7.63 to 12.73 & 18.84 & 9.63 & 26.10 & 0.973 & 10.14 \\
\hline $\mathrm{BC}_{2} \mathrm{~F}_{2}$ & 9.23 & 6.6 to 11.53 & 20.63 & 10.48 & 25.80 & 1.01 & 10.97 \\
\hline \multicolumn{8}{|c|}{ 4. Number of Branches per plant } \\
\hline$F_{2}$ & 1.428 & 0.33 to 3.66 & 70.5 & 28.43 & 16.3 & 0.337 & 23.62 \\
\hline $\mathbf{F}_{3}$ & 1.78 & 0.66 to 3.66 & 62.48 & 27.91 & 20.00 & 0.46 & 25.69 \\
\hline $\mathbf{B C}_{1} \mathbf{F}_{2}$ & 1.60 & 0.33 to 3.66 & 73.94 & 40.03 & 29.30 & 0.716 & 44.65 \\
\hline $\mathrm{BC}_{2} \mathbf{F}_{2}$ & 1.71 & 0.33 to 2.67 & 47.91 & 23.87 & 24.80 & 0.42 & 24.50 \\
\hline \multicolumn{8}{|c|}{ 5. Number of Nodes Per Plant } \\
\hline $\mathbf{F}_{2}$ & 18.08 & 11.66 to 25.30 & 29.08 & 12.48 & 18.40 & 1.99 & 11.03 \\
\hline
\end{tabular}




\begin{tabular}{|c|c|c|c|c|c|c|c|}
\hline $\mathbf{F}_{3}$ & 16.69 & 8.00 to 20.66 & 22.29 & 10.44 & 21.90 & 1.68 & 10.07 \\
\hline $\mathrm{BC}_{1} \mathrm{~F}_{2}$ & 14.79 & 9.66 to 20.33 & 27.95 & 15.19 & 29.60 & 2.51 & 17.01 \\
\hline $\mathrm{BC}_{2} \mathrm{~F}_{2}$ & 15.96 & 8.00 to 20.66 & 23.83 & 11.36 & 22.70 & 1.78 & 11.15 \\
\hline \multicolumn{8}{|c|}{ 7. Length Of Fruit (cm) } \\
\hline $\mathbf{F}_{2}$ & 11.89 & 5.56 to 16.33 & 28.29 & 12.66 & 20.00 & 1.38 & 11.67 \\
\hline $\mathbf{F}_{3}$ & 11.83 & 7.33 to 18.00 & 37.48 & 16.33 & 19.00 & 1.73 & 14.65 \\
\hline $\mathrm{BC}_{1} \mathbf{F}_{2}$ & 12.89 & 9.40 to 23.15 & 34.41 & 20.00 & 33.80 & 3.09 & 23.96 \\
\hline $\mathbf{B C}_{2} \mathbf{F}_{2}$ & 9.80 & 6.50 to 15.00 & 38.02 & 18.84 & 24.50 & 1.89 & 19.22 \\
\hline \multicolumn{8}{|c|}{ 8. Fruit Diameter (mm) } \\
\hline $\mathbf{F}_{2}$ & 18.51 & 13.70 to 23.03 & 20.00 & 8.37 & 17.50 & 1.34 & 7.20 \\
\hline $\mathbf{F}_{\mathbf{3}}$ & 19.00 & 15.16 to 24.90 & 19.00 & 8.99 & 22.40 & 1.66 & 8.77 \\
\hline $\mathbf{B C}_{1} \mathbf{F}_{2}$ & 13.66 & 8.39 to 18.50 & 29.80 & 15.39 & 26.70 & 2.23 & 16.37 \\
\hline $\mathrm{BC}_{2} \mathrm{~F}_{2}$ & 20.29 & 16.93 to 25.73 & 14.97 & 7.87 & 27.60 & 1.73 & 8.53 \\
\hline \multicolumn{8}{|c|}{ 9. No. Of fruit Per Plant } \\
\hline $\mathbf{F}_{2}$ & 22.18 & 14.00 to 32.66 & 28.62 & 12.64 & 19.50 & 2.55 & 11.51 \\
\hline $\mathbf{F}_{3}$ & 21.75 & 12.00 to 31.66 & 28.10 & 12.33 & 19.30 & 2.42 & 11.15 \\
\hline $\mathrm{BC}_{1} \mathrm{~F}_{2}$ & 19.06 & 11.33 to 26.00 & 36.01 & 18.65 & 26.80 & 3.79 & 19.89 \\
\hline $\mathrm{BC}_{2} \mathbf{F}_{2}$ & 20.98 & 14.33 to 28.30 & 24.87 & 11.99 & 23.30 & 2.50 & 11.92 \\
\hline \multicolumn{8}{|c|}{ 9. Fruit Weight (g) } \\
\hline $\mathbf{F}_{2}$ & 18.60 & 10.33 to 29.3 & 36.12 & 16.06 & 19.80 & 2.74 & 14.72 \\
\hline $\mathbf{F}_{\mathbf{3}}$ & 22.92 & 10.33 to 23 & 25.8 & 10.78 & 18.50 & 1.69 & 9.54 \\
\hline $\mathbf{B C}_{1} \mathbf{F}_{2}$ & 17.36 & 11.60 to 23.60 & 27.54 & 17.88 & 42.20 & 4.15 & 23.92 \\
\hline $\mathrm{BC}_{2} \mathrm{~F}_{2}$ & 15.98 & 8.00 to 22.30 & 30.84 & 14.58 & 22.40 & 2.27 & 14.21 \\
\hline \multicolumn{8}{|c|}{ 10. fruit Yield Per Plant (g) } \\
\hline $\mathbf{F}_{2}$ & 305.17 & 141.60 to 513.3 & 39.75 & 16.82 & 17.90 & 44.74 & 14.66 \\
\hline $\mathbf{F}_{3}$ & 290.78 & 140.00 to 475.33 & 41.46 & 20.47 & 24.40 & 60.57 & 20.83 \\
\hline $\mathrm{BC}_{1} \mathrm{~F}_{2}$ & 325.12 & 178.60 to 547.60 & 42.04 & 21.53 & 26.20 & 73.83 & 22.71 \\
\hline $\mathrm{BC}_{2} \mathrm{~F}_{2}$ & 302.12 & 130.00 to 451.00 & 37.48 & 19.07 & 25.40 & 60.41 & 19.99 \\
\hline
\end{tabular}

The result obtained confirm the earlier report of Meena et al., (2013), Sharma et al.,(2014), Guddadamath et al., (2011), Yonas et al., (2014), Singh et al., (2017).

The PCV was observed 39.75, 41.46, 42.04 and 37.48 per cent in $\mathrm{F}_{2}, \mathrm{~F}_{3}, \mathrm{BC}_{1} \mathrm{~F}_{2}$ and $\mathrm{BC}_{2} \mathrm{~F}_{2}$ generations respectively for the trait fruit yield per plant $(\mathrm{g})$. Whereas, GCV observed was 16.82, 20.47, 21.53 and 19.07 per cent in $\mathrm{F}_{2}$, $\mathrm{F}_{3}, \mathrm{BC}_{1} \mathrm{~F}_{2}$ and $\mathrm{BC}_{2} \mathrm{~F}_{2}$ generations respectively. High PCV and GCV values were exhibited by the $\mathrm{BC}_{1} \mathrm{~F}_{2}$ population followed by $\mathrm{F}_{3}, \mathrm{~F}_{2}$ and $\mathrm{BC}_{2} \mathrm{~F}_{2}$ population. The result obtained in the present study were in accordance with report AdeOluwa et al.,(2011), Yonas et al., (2014), Ahmad et al.,(2017), Akotkar et al., (2010), Meena et al., (2013), Guddadamath et al., (2011), Yonas et al., (2014), Shivaramegowda et al.,(2016), Das et al.,(2012), Singh et al., (2017).

The estimated of high genotypic and phenotypic coefficient of variation were 
observed for number of nodes per plant and fruit weight in $\mathrm{F}_{2}$ generation, internodal length in $\mathrm{F}_{3}$ generation, plant height, number of branches per plant, fruit diameter, number of fruit per plant and fruit yield per plant in $\mathrm{BC}_{1} \mathrm{~F}_{2}$ generation, length of fruit in $\mathrm{BC}_{2} \mathrm{~F}_{2}$ generation. The estimated of heritability was appreciably moderate for fruit weight in $\mathrm{BC}_{1} \mathrm{~F}_{2}$. Higher heritability indicated less influence of environments. Hence, selection for this generation would be rewarding. The genetic advance as per cent of mean was appreciably high for fruit yield per plant in $\mathrm{BC}_{1} \mathrm{~F}_{2}$ and moderate for fruit weight and number of fruit per plant in $F_{2}$ and $B_{1} F_{2}$ generation respectively. The high GAM indicated influence of additive genetic action.

\section{References}

Akotkar, P. K., De, D. K. and Pal, A. K. (2010). Genetic variability and diversity in okra (Abelmoschus esculentus (L.) Moench). Elec. J. Plant Breed., 1(4): 393-398.

Alam, A. K. M. A. and Hossain, M. M. (2008). Variability of different growth contributing Parameters of some okra (Abelmoschus esculentus (L.) Moench) accession and their interrelation effects of yield. J. Agric. Rural Dev., 6 (1\&2): 25-35.
Badiger, M., Pitchaimuthu, M. and Pujer P. (2017). Genetic variability heritability genetic advance and correlation studies among quantitative traits in okra (Abelmoschus esculentus (L.) Moench). Global J. Biosci. Biotech., 6(2): 314-319.

Burton, G.W. (1952). Quantitative inheritance in grasses. Proc. $6^{\text {th }}$ Int. Grassland Congr., 1:277.283

Goswami, A., Singh B. and Anju Singh (2014). Study of genetic variability, heritability and genetic advance in okra (Abelmoschus esculentus (L.) Moench). Prog Agric., 14(1): 57-62.

Guddadamath, Somashekhar, Mohankumar, H. D. and Salimath, P. M. (2011). Genetic analysis of segregating population for yield in okra (Abelmoschus esculentus (L.) Moench). Karnataka J. Agric. Sci., 24(2):114-117.

Johnson, H. W., Robinson H. F. and Comstock R. E. (1955). Estimates of genetic and environmental variability in soyabean. Agron. J., 47: 314-318.

Ullangula Sravanthi (2017). Studies on variability, heritability and genetic advance in okra (Abelmoschus esculentus (L.) Moench). Int. J. Curr. Microbiol. App. Sci., 6(10): 18341838.

\section{How to cite this article:}

Tukaram A. Chavan, P. B. Wadikar, B. R. Chavan and Naik, G. H. 2019. Genetic Variability Study in Segregating Generations of Okra (Abelmoschus esculentus L.). Int.J.Curr.Microbiol.App.Sci. 8(09): 2270-2275. doi: https://doi.org/10.20546/ijcmas.2019.809.262 